Penelitian

\title{
Deteksi Virus African Swine Fever dari Sampah Makanan Kapal Laut Internasional di Pelabuhan Tanjung Priok
}

\author{
Detection of African Swine Fever Virus from International Ship's Food Waste \\ at Tanjung Priok Port
}

\author{
Putut Isworo Arimurti ${ }^{1,2 *}$, Chaerul Basri³, Denny Widaya Lukman³ \\ 1Balai Besar karantina Pertanian Tanjung Priok, Badan Karantina Pertanian \\ ${ }^{2}$ Program Studi Kesehatan Masyarakat Veteriner Sekolah Pascasarjana Institut Pertanian Bogor \\ ${ }^{3}$ Departemen Ilmu Penyakit Hewan dan Kesehatan Masyarakat Veteriner, Fakultas Kedokteran Hewan, \\ Institut Pertanian Bogor \\ *Penulis untuk korespondensi: pututisworo84@gmail.com \\ Diterima 27 Maret 2021, Disetujui 29 Juni 2021
}

\begin{abstract}
ABSTRAK
Sampah makanan kapal dihasilkan dari sampah dapur dan atau restoran yang berasal dari kru kapal atau penumpang. Sampah makanan kapal laut internasional yang diturunkan di Pelabuhan Tanjung Priok berpotensi sebagai media pembawa virus African swine fever (ASF) ke Indonesia. Penelitian ini bertujuan untuk mendeteksi keberadaan virus ASF dari sampah makanan kapal laut internasional yang berasal atau transit dari negara tertular ASF di Pelabuhan Tanjung Priok. Jumlah sampel dari setiap negara dihitung secara proporsional dari data jumlah frekuensi kedatangan kapal. Sebanyak 23 sampel pooling sampah makanan yang mengandung daging babi didapatkan dari 23 kapal yang berasal dari 5 negara tertular ASF yaitu China, Hong Kong, Vietnam, Filipina, dan Korea Selatan. Sampel diuji dengan real-time PCR di Balai Besar Uji Standar Karantina Pertanian menggunakan kit ekstraksi dan master mix komersial serta primer King seperti yang direkomendasikan oleh OIE. Hasil penelitian menunjukkan dari total 23 sampel yang diambil sebanyak 2 sampel positif (8,69\%) mengandung virus ASF. Sampel positif tersebut berasal dari kapal China dan Filipina. Keberadaan virus ASF pada sampah makanan tersebut menunjukkan indikasi bahwa sampah makanan dari kapal laut internasional dapat menjadi jalur masuknya ASF ke Indonesia.
\end{abstract}

Kata kunci: African swine fever, kapal laut, real-time PCR, sampah makanan

\begin{abstract}
Ship's food waste was generated from the kitchen and or the restaurant originating from ships crews or passengers. International ship's food waste that is disposed at Tanjung Priok Port has the potential to carry African swine fever (ASF) to Indonesia. This study is aimed to detect the presence of the ASF virus from international ship's food waste originating or transiting from ASF-infected countries at Tanjung Priok Port. The number of samples from each country which was calculated proportionally from the data on the frequency of ship arrivals. A total of 23 pooling samples of food waste containing pork were obtained from 23 ships from 5 ASF-infected countries, i.e., China, Hong Kong, Vietnam, Philippines, and South Korea. Samples were tested with real-time PCR at The Center for Diagnostic of Agricultural Quarantine using extraction kits and commercial master mixes and King's primer as recommended by OIE. The results showed that from total of 23 samples, there were 2 positive samples $(8.69 \%)$ containing the ASF virus. Those positive samples were from China and Philippines ships. The presence of the ASF virus in food waste indicates that food waste from international ships can be the entry route for ASF to Indonesia.
\end{abstract}

Keywords: African swine fever, food waste, real-time PCR, ship 


\section{PENDAHULUAN}

African swine fever (ASF) atau demam babi afrika adalah penyakit menular pada babi yang disebabkan oleh African swine fever virus (ASFV). Virus ini dapat menginfeksi babi domestik maupun babi liar dengan morbiditas dan mortalitas dapat mencapai 100\% (CFSPH, 2019). Kejadian ASF pertama kali dilaporkan pada tahun 1921 di Kenya, Afrika (Montgomery, 1921). ASF dapat menular melalui kontak langsung maupun tidak langsung serta melalui caplak Ornithodoros sp. yang berperan sebagai vektor biologis (EFSA, 2014). Penularan langsung terjadi melalui kontak fisik antara babi terinfeksi dengan babi sehat (Guinat et al., 2016), sedangkan penularan tidak langsung terjadi melalui kendaraan, pakan, dan peralatan yang terkontaminasi (fomites), serta sampah makanan terkontaminasi yang diberikan kepada babi (CFSPH, 2019).

Saat ini ASF dilaporkan telah menyebar ke berbagai negara Eropa dan Asia (OIE, 2020). Wabah ASF pertama kali dilaporkan terjadi di Asia pada bulan Agustus 2018 di Kota Shenyang, Provinsi Liaoning, China (Zhou et al., 2018). Wabah selanjutnya menyebar ke Mongolia (Januari 2019), Vietnam (Februari 2019), Kamboja (Maret 2019), Hong Kong (Mei 2019), Korea Utara (Mei 2019), Laos (Juni 2019), Filipina (Juli 2019), Myanmar (Agustus 2019), Korea Selatan (September 2019), Timor Leste (September 2019), Indonesia (Desember 2019), dan Papua Nugini (Maret 2020) (OIE 2020). Penyakit ASF dikelompokkan dalam penyakit lintas batas (transboundary animal diseases) karena sifat penyebarannya yang sangat cepat ke berbagai negara melalui lalu lintas babi dan produknya (Beltran-Alcrudo et al., 2019).

Wabah ASF di Indonesia pertama kali dilaporkan terjadi pada bulan Desember 2019 di wilayah Medan, Sumatera Utara (OIE, 2020). Studi dari Sendow et al. (2020) menyebutkan salah satu kemungkinan jalur masuknya ASF ke Indonesia terjadi melalui swill feeding menggunakan sampah sisa makanan dari transportasi internasional. Swill feeding dapat berupa sisa katering pesawat udara dan kapal laut internasional, atau barang sitaan dari penumpang berupa makanan yang mengandung daging babi dan produknya (Penrith et al., 2013). Sampah makanan dari transportasi internasional seharusnya dibuang atau dimusnahkan di tempat pembuangan sampah khusus, namun yang sering terjadi sisa makanan tersebut justru dikumpulkan dan digunakan sebagai pakan babi.

Pelabuhan Tanjung Priok merupakan pelabuhan terbesar dan tersibuk di Indonesia dengan frekuensi lalu lintas kapal laut yang tinggi. Hal ini terkait dengan banyaknya aktivitas perdagangan barang ekspor-impor maupun antar pulau. Kapal laut internasional yang singgah di Pelabuhan Tanjung Priok selain melakukan bongkar muat sering kali juga menurunkan sampahnya di pelabuhan. Sampah sisa makanan penumpang atau kru kapal dari kapal negara tertular ASF yang ikut diturunkan berpotensi sebagai media pembawa virus ASF ke Indonesia. Menurut EFSA (2018), sampah sisa makanan yang berasal dari daging babi yang mengandung virus ASF aktif dapat menjadi sumber infeksi penularan virus ASF jika diberikan kepada babi.

Penelitian ini bertujuan untuk mendeteksi keberadaan virus ASF dari sampah makanan kapal laut internasional di Pelabuhan Tanjung Priok. Hasil penelitian ini diharapakan dapat dimanfaatkan sebagai bahan masukan dalam penyusunan peraturan terkait penanganan sampah makanan kapal laut serta dapat digunakan untuk pengambilan kebijakan dalam upaya pencegahan masuknya virus ASF melalui sampah pelabuhan.

\section{BAHAN DAN METODE}

\section{Tempat dan Waktu Penelitian}

Penelitian ini dilaksanakan di Balai Besar Karantina Pertanian Tanjung Priok (BBKP Tanjung Priok). Pengujian sampel dilakukan di Laboratorium Balai Besar Uji Standar Karantina Pertanian (BBUSKP). Pengolahan data dilakukan di Divisi Kesehatan Masyarakat Veteriner, Departemen Ilmu Penyakit Hewan dan Kesehatan Masyarakat Veteriner, Fakultas Kedokteran Hewan, Institut Pertanian Bogor. Waktu penelitian dilaksanakan pada bulan September 2020 sampai Februari 2021.

\section{Bahan}

Bahan yang digunakan adalah kit ekstraksi QuickDNA $^{\mathrm{TM}}$ Miniprep Plus Kit (Zymo Research, USA), kit Master Mix SensiFAST Probe No-ROX Kit (Bioline Reagents Ltd, UK), Primer dan probe King et al. (2003) yang terdiri atas forward primers 5'- CTC CTC ATC GTA TCA ATC TTA TCG A-3', reserve primers 5'- GAT ACC ACA AGA TCR GCC GT-3', dan Probe 5'FAM_CCA CGG GAG GAA TAC CAA AGT G_TAMRA-3'. Kontrol positif sintetis virus ASF panjang amplikon 455 bp berasal dari sekuen template gabungan strain N10 GenBank: MH025919.1 Region 103772103879 (108 bp) dan gen B646L (p72) strain: ZAM/2017/Mbala/1 Acces no. LC322016.1 Region: 149438 (347 bp). 


\section{Populasi dan Sampel Penelitian}

Berdasarkan data dari Pelindo (2020) diketahui bahwa jumlah frekuensi kedatangan kapal laut internasional yang berasal dari negara tertular ASF di Pelabuhan Tanjung Priok pada periode bulan Januari sampai dengan Mei 2020 adalah sebanyak 208 kapal. Kapal tersebut berasal dari China, Vietnam, Korea Selatan, Filipina, Hong Kong, Korea Utara, dan Rusia. Data tersebut disajikan pada Tabel 1.

Jumlah sampel kapal dihitung dengan rumus deteksi penyakit (Martin et al., 1987). Berdasarkan asumsi prevalensi dugaan $10 \%$ dan tingkat kepercayaan $95 \%$, maka sampel yang diambil sebanyak 23 kapal. Jumlah sampel dari setiap negara dihitung secara proporsional dari data jumlah frekuensi kedatangan kapal pada data Tabel 1.

Dari masing-masing kapal terpilih, diambil sebanyak 5 sampel sampah sisa makanan. Kriteria sampel yang diambil adalah (1) sampel sampah makanan kapal laut yang berasal atau transit dari negara tertular virus ASF, dan (2) jenis sampah makanan yang mengandung daging babi. Sebanyak 5 sampel dari masing-masing kapal terpilih tersebut kemudian dipooling menjadi 1 sampel sehingga total didapatkan 23 sampel pooling . Sampel diambil dari sampah makanan yang diturunkan dari kapal di hari dan tanggal berbeda sampai jumlah sampel kapal terpenuhi.

\section{Metode Pengujian}

Pengujian sampel dilakukan dengan real-time PCR. Langkah pertama pengujian adalah mengekstraksi DNA dari setiap sampel sampah makanan dengan Quick-DNA ${ }^{\mathrm{TM}}$ Miniprep Plus Kit (Zymo Research, USA), penggunaan sesuai rekomendasi manufaktur. Sampel sampah makanan masing-masing ditimbang sebanyak 0,025 g, kemudian dimasukkan ke dalam microtube $1,5 \mathrm{ml}$, selanjutnya ditambahkan RNAse free water $95 \mu \mathrm{l}$, solid tissue water $95 \mu \mathrm{l}$, dan proteinase $\mathrm{K} 10 \mu \mathrm{l}$, lalu dihomogenkan. Hasil ekstraksi tersebut dimasukkan ke dalam waterbath dengan suhu $55{ }^{\circ} \mathrm{C}$ selama 60 menit, kemudian dihomogenkan dengan tube shaker, lalu disentrifus pada kecepatan $12.000 \mathrm{xg}$ selama 1 menit sehingga diperoleh supernatan $\pm 180 \mu$ l.

Supernatan yang dihasilkan dimasukkan ke dalam microtube $1,5 \mathrm{ml}$, kemudian ditambahkan genomic binding buffer sebanyak $2 x$ supernatan $( \pm 360 \mu \mathrm{l})$, lalu dihomogenkan. Larutan tersebut dipindahkan ke tabung zymo-spin column, disentrifus $12.000 \mathrm{xg}$ selama 1 menit, kemudian collection tube dibuang dan diganti yang baru. Selanjutnya ditambahkan $400 \mu \mathrm{l}$ DNA pre-wash buffer, disentrifus pada pada kecepatan $12.000 \mathrm{xg}$ selama 1 menit, kemudian collection tube dibuang dan diganti dengan yang baru. Setelah itu ditambahkan $700 \mu \mathrm{l}$ g-DNA wash buffer, disentrifus pada kecepatan $12.000 \mathrm{xg}$ selama 1 menit, kemudian collection tube dibuang dan diganti dengan yang baru. Selanjutnya ke dalam larutan tersebut ditambahkan $200 \mu$ g-DNA wash buffer, disentrifus pada pada kecepatan $12.000 \mathrm{xg}$ selama 1 menit, kemudian collection tube dibuang. Berikutnya adalah pembuatan elusi DNA yaitu zymo-spin column diletakkan ke dalam microtube steril $1,5 \mathrm{ml}$, kemudian ditambahkan $50 \mu \mathrm{l}$ DNA elution buffer. Hasil elusi DNA tersebut diinkubasi selama 5 menit pada suhu ruang, selanjutnya disentrifus pada kecepatan $12.000 \times g$ selama 1 menit. DNA hasil elusi dapat langsung digunakan untuk proses amplifikasi PCR atau disimpan ke dalam freezer $-40^{\circ} \mathrm{C}$.

Tabel 1 Jumlah frekuensi kedatangan kapal laut internasional yang berasal dari negara tertular ASF di Pelabuhan Tanjung Priok periode bulan Januari-Mei 2020

\begin{tabular}{|c|c|c|c|c|c|c|c|}
\hline \multirow{2}{*}{$\begin{array}{l}\text { Asal negara/ } \\
\text { Negara transit }\end{array}$} & \multicolumn{5}{|c|}{ Bulan } & \multirow{2}{*}{$\begin{array}{l}\text { Jumlah } \\
\text { total } \\
\text { kapal }\end{array}$} & \multirow{2}{*}{$\begin{array}{l}\text { Jumlah rata- } \\
\text { rata kapal per } \\
\text { bulan }\end{array}$} \\
\hline & Januari & Februari & Maret & April & Mei & & \\
\hline China & 35 & 20 & 32 & 32 & 15 & 134 & 27 \\
\hline Vietnam & 5 & 5 & 6 & 7 & 6 & 29 & 6 \\
\hline Korea Selatan & 2 & 5 & 2 & 3 & 1 & 13 & 3 \\
\hline Filipina & 6 & 3 & 1 & 2 & 0 & 12 & 3 \\
\hline Hong Kong & 2 & 2 & 3 & 3 & 2 & 12 & 3 \\
\hline Korea Utara & 1 & 0 & 2 & 1 & 0 & 4 & 1 \\
\hline \multirow[t]{2}{*}{ Rusia } & 1 & 2 & 1 & 0 & 0 & 4 & 1 \\
\hline & & & & & & 208 & 44 \\
\hline
\end{tabular}


Langkah kedua adalah proses amplifikasi PCR. Proses amplifikasi diawali dengan penambahan master mix PCR menggunakan SensiFAST Probe No-ROX Kit (Bioline Reagents Ltd, UK), penggunaan sesuai rekomendasi manufaktur. Setiap pengujian real-time PCR selalu disertai kontrol positif dan kontrol negatif. Setiap sampel yang diuji dengan real-time PCR dilakukan ulangan sebanyak 2 kali. Bahan master mix dalam 1 kali reaksi terdiri atas $\mathrm{H}_{2} \mathrm{O} 3,2 \mu \mathrm{l}$, 2x SensiFAST Probe NoROX mix $10 \mu \mathrm{l}$, forward primer $(0,4 \mu \mathrm{M}) 0,8 \mu \mathrm{l}$, reverse primer $(0,4 \mu \mathrm{M}) 0,8 \mu \mathrm{l}$, primer probe $(0,2 \mu \mathrm{M}) 0,2 \mu \mathrm{l}$. Bahan-bahan tersebut dimasukkan ke dalam tabung microtube ukuran $1,5 \mathrm{ml}$, kemudian dihomogenkan. Larutan master mix yang dihasilkan didistribusikan sebanyak $15 \mu \mathrm{l}$ ke dalam tube PCR untuk setiap sampel. Setiap sampel yang akan diidentifikasi memerlukan 15 $\mu \mathrm{l}$ larutan master mix ditambah $5 \mu$ lemplate DNA sehingga total reaksi adalah sebanyak $20 \mu \mathrm{l}$.

Langkah ketiga adalah menempatkan tube PCR ke dalam mesin amplifikasi PCR thermal cycler Rotor-Gene Q (Qiagen, Germany). Program amplifikasi pada metode uji real-time $\mathrm{PCR}$ yaitu aktivasi enzim $95{ }^{\circ} \mathrm{C}$ selama 3 menit, denaturasi $95^{\circ} \mathrm{C}$ selama 10 detik, dan annealing/extension/data acquisition $60^{\circ} \mathrm{C}$ selama 30 detik, dengan siklus sebanyak 40 kali. Terakhir adalah analisis hasil uji dengan menggunakan perangkat Rotor-Gene Q Series Software 2.3.1.49 (Qiagen, Germany). Interpretasi dilihat berdasarkan nilai Ct (cycle threshold) yang dihasilkan pada plot amplifikasi cycle threshold. Hasil positif ditunjukkan jika sampel uji mempunyai nilai $\mathrm{Ct}<37$, sedangkan hasil negatif ditunjukkan dengan nilai $\mathrm{Ct}>40$, dan jika terdapat nilai $\mathrm{Ct}$ antara 37 -40 , maka pengujian diulang.

\section{Analisis Data}

Data yang diperoleh dianalisis secara deskriptif untuk menggambarkan keberadaan virus ASF dari sampah makanan kapal laut internasional di Pelabuhan Tanjung Priok. Hasil uji disajikan dalam bentuk tabel dan gambar.

\section{HASIL}

Sampel sampah makanan diperoleh dari sampah dapur seperti sisa-sisa potongan daging babi dan tulang serta sampah dari restoran berupa sisa-sisa katering kru kapal seperti olahan daging babi, bacon, bakso, sosis, dan steak. Sampel diambil dari 23 kapal yang terpilih sesuai kriteria, dari masing-masing kapal tersebut diambil sebanyak 5 sampel sampah sisa makanan. Sampel kemudian dipooling dengan cara mencampur 5 sampel dari masing-masing kapal yang terpilih menjadi 1 sampel sehingga total didapatkan 23 sampel pooling. Periode pengambilan sampel dimulai dari tanggal 18 November 2020 dan target jumlah sampel terpenuhi pada tanggal 2 Desember 2020.

Sampel yang didapat berasal dari 5 negara tertular ASF yaitu China, Vietnam, Filipina, Hong Kong, dan Korea Selatan, sedangkan sampel dari Korea Utara dan Rusia tidak didapatkan karena dalam periode pengambilan sampel sampai dengan jumlah target sampel terpenuhi tidak ada kapal yang dijumpai berasal dari negara tersebut. Sampel yang didapatkan berasal dari kapal China sebanyak 11 sampel, Vietnam 4 sampel, Filipina 3 sampel, Hong Kong 3 sampel, dan Korea Selatan 2 sampel. Sampel tersebut selanjutnya dibawa ke BBUSKP dan diuji dengan real-time PCR untuk mendeteksi keberadaan virus ASF.

Hasil pengujian real-time PCR diperoleh yaitu dari total 23 sampel sampah makanan kapal laut internasional yang diambil sebanyak 2 sampel positif $(8,69 \%)$ mengandung virus ASF. Sampel positif tersebut berasal dari kapal China dan Filipina. Persentase sampel positif dari kapal China adalah 9,09\% (1/11) dan dari kapal Filipina adalah 33,33\% (1/3). Hasil uji dapat dilihat pada Tabel 2.

Tabel 2 Hasil pengujian sampel sampah makanan kapal laut internasional dengan metode real-time PCR

\begin{tabular}{llccc}
\hline No. & Negara asal & Jumlah sampel & Jumlah positif & Persentase (\%) \\
\hline 1 & China & 11 & 1 & 9,09 \\
2 & Vietnam & 4 & 0 & 0 \\
3 & Filipina & 3 & 1 & 33,33 \\
4 & Hong Kong & 3 & 0 & 0 \\
5 & Korea Selatan & 2 & 0 & 0 \\
\hline & Total & 23 & 2 & 8,69 \\
\hline
\end{tabular}




\section{PEMBAHASAN}

Sampah makanan kapal dihasilkan dari sampah dapur dan atau restoran yang berasal dari kru kapal atau penumpang (EMSA, 2017). Menurut IMO (2005) mendefinisikan sampah makanan sebagai bahan makanan yang mudah busuk atau yang tidak mudah busuk termasuk buah-buahan, sayuran, produk susu, produk daging, dan sisa makanan yang dihasilkan diatas kapal. Jumlah dan komposisi sisa makanan di kapal bergantung pada beberapa parameter termasuk jenis kapal, pilihan menu, dan strategi penyortiran (Oreopoulou dan Tzia, 2007). Menurut EMSA (2017), sampah makanan yang dihasilkan kru kapal laut kargo internasional adalah 0,01-0,016 $\mathrm{m}^{3} /$ orang/hari atau $0,3 \mathrm{~kg} /$ orang/hari, sedangkan untuk sampah anorganik adalah 0,02-0,03 $\mathrm{m}^{3} /$ orang/hari atau 1,4 kg/orang/hari. Jumlah kru kapal kargo terdiri atas 20 sampai 30 orang per kapal (Universal Cargo, 2018).

Ketentuan Marpol 1973/1978 Annex V melarang pembuangan sampah plastik ke laut termasuk kantong sampah yang terbuat dari plastik, tali sintetis dan jaring sintetis. Khusus sampah makanan dapat diijinkan dibuang ke laut dengan jarak sejauh 12 mil dari daratan terdekat, dengan ketentuan sampah tersebut telah digiling dan dapat menembus saringan kisi-kisi tidak lebih dari $25 \mathrm{~mm}$. Sampah makanan juga diijinkan dikirim ke fasilitas penampungan limbah pelabuhan atau Port Reception Facilities (PRF) jika pembuangan di laut tidak diizinkan karena peraturan atau karena kapal tidak mempunyai alat komuter/mesin penghancur sampah. Adanya ketentuan ini menjadikan pelabuhan wajib mengembangkan rencana dan menyediakan pengelolaan fasilitas dan perlengkapan penerimaan sampah yang memadai (IMO, 2006).

Berdasarkan informasi dari pihak Pelindo, Pelabuhan Tanjung Priok saat ini sudah mempunyai PRF di kawasan pelabuhan tetapi hanya khusus dipergunakan dalam pengelolaan limbah bahan berbahaya dan beracun (B3), sedangkan untuk sampah yang dihasilkan oleh penumpang atau kru kapal termasuk kapal laut internasional belum mempunyai fasilitas insinerasi atau pembuangan khusus. Sampah penumpang berupa sampah organik dan anorganik yang diturunkan di pelabuhan selama ini hanya dikumpulkan oleh pihak mitra pelayanan sampah. Sampah-sampah tersebut kemudian diangkut ke tempat pembuangan sampah umum yang lokasinya berada diluar pelabuhan tanpa ada perlakuan maupun penanganan khusus. Sampah makanan yang berasal dari transportasi internasional secara hukum harus dibuang ke dalam suatu insinerator atau suatu tempat pembuangan sampah khusus (Adkin et al., 2008). Katering dan sisa makanan lainnya dari pesawat dan kapal seringkali berimplikasi dalam wabah penyakit menular, terutama agen patogen eksotik (Beltran-Alcrudo et al., 2019).

Data Pelindo (2020) menyebutkan jumlah produksi sampah kapal laut internasional yang diturunkan di Pelabuhan Tanjung Priok pada tahun 2019 adalah sebesar $12.336 \mathrm{~m}^{3}$. Sampah tersebut dihasilkan dari 3765 kapal atau sekitar 3,3 $\mathrm{m}^{3}$ sampah yang dihasilkan setiap kapal. Berdasarkan observasi di lapangan, sampah-sampah tersebut dikumpulkan dan langsung diangkut ke tempat pembuangan

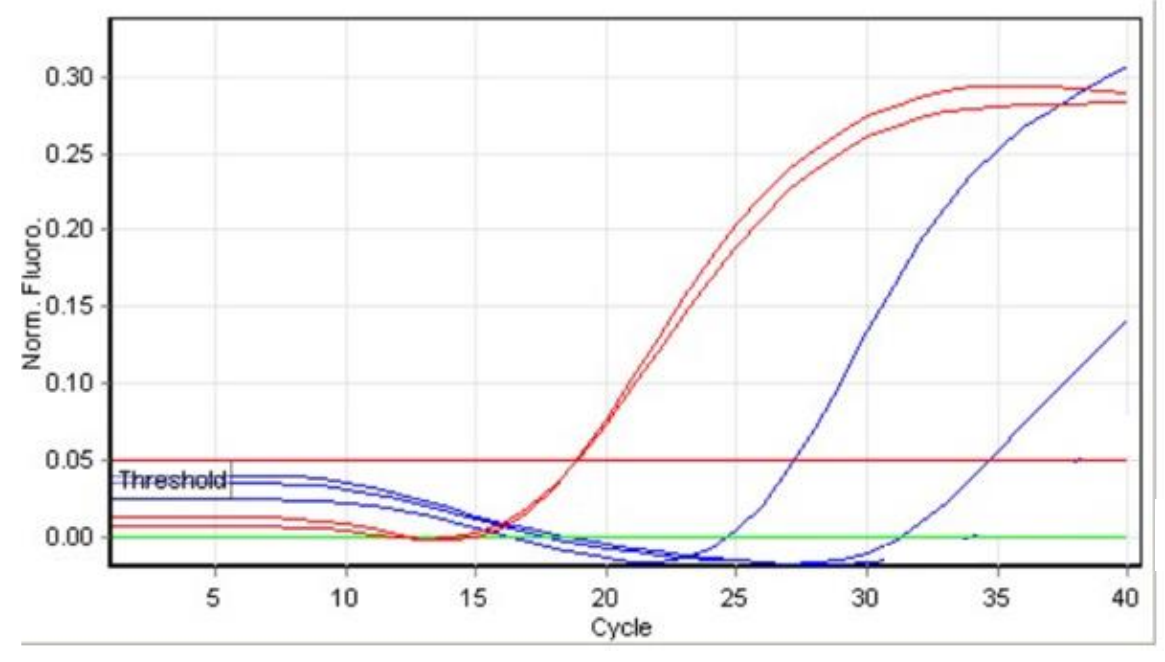

Sampel kapal China (Ct 27,23)

Kontrol positif (Ct 18,89)

Kontrol positif (Ct 18,87)

Sampel kapal Filipina $(C t$ 34,68)

Kontrol negatif

Gambar 1 Plot amplifikasi real-time PCR pada sampel uji positif 
116 | Arimurti et al.

sampah umum sehingga berpotensi sebagai salah satu jalur masuknya agen patogen eksotik ke Indonesia, salah satunya adalah virus African swine fever (ASF). Data dari Pelindo menunjukkan sampah yang diangkut berasal dari 5-7 kapal internasional setiap harinya dengan 2-3 kapal berasal dari negara tertular ASF.

Selama berlayar kapal laut membawa bahan makanan yang digunakan sebagai stok persediaan makanan untuk penumpang atau kru kapal. Stok bahan makanan tersebut disimpan dalam tempat penyimpanan dingin (cold storage). Bahan makanan terutama adalah daging, buah- buahan, dan sayuran yang digunakan untuk menu katering. Stok daging yang dibawa sebagian besar adalah daging babi metah, hal ini disebabkan rata- rata kru kapal berasal dari negara pengonsumsi daging babi seperti China, Vietnam, Korea, Vietnam, Filipina, dan Jepang. Stok daging babi yang diolah di dapur serta menu katering yang tidak habis dimakan oleh kru kapal sering kali menghasilkan sisa-sisa yang dibuang ke tempat sampah.

Sisa-sisa daging babi yang dibuang dalam keadaan mentah dan atau sisa-sisa katering yang diolah setengah matang yang dibuang ke tempat sampah masih berpotensi mengandung virus ASF aktif. Virus ASF masih dapat bertahan hidup di dalam produk daging babi mentah atau kurang matang dalam jangka waktu yang lama. Virus ASF dapat bertahan pada daging dingin selama 110 hari dan daging beku 1000 hari (Beltran-Alcrudo et al., 2017; MazurPanasiuk et al., 2019). Selain itu virus ini dapat bertahan dalam penyimpanan suhu $-80{ }^{\circ} \mathrm{C}$ selama bertahun-tahun dan suhu $-20^{\circ} \mathrm{C}$ hingga 65 minggu (Mazur-Panasiuk et al., 2019). Menurut literatur, virus ASF pada daging babi dapat diinaktivasi jika telah dilakukan pemanasan pada suhu minimum $70^{\circ} \mathrm{C}$ selama minimum 30 menit (Beltran-Alcrudo et al., 2017).

Hasil pengujian real-time PCR yaitu dari total 23 sampel sampah makanan kapal laut internasional yang diambil sebanyak 2 sampel positif (8,69\%) mengandung virus ASF. Sampel positif berasal dari kapal China dan kapal Filipina. Persentase sampel positif dari kapal China adalah 9,09\% (1/11) dan dari kapal Filipina adalah 33,33\% (1/3). Sampel positif tersebut dapat mengindikasikan bahwa produk babi yang dibawa kemungkinan berasal dari pemotongan hewan yang terinfeksi virus ASF atau berasal dari produk babi yang telah terkontaminasi. Kontaminasi virus ASF secara tidak langsung dapat terjadi melalui benda yang tercemar (fomites) seperti pakaian, sepatu, kendaran, pisau, peralatan, dan orang yang tercemar (OIE, 2019).
Plot amplifikasi real-time $P C R$ pada sampel uji positif ditunjukkan dengan nilai $\mathrm{Ct}<37$. Sampel positif dari kapal China ditunjukkan dengan nilai Ct 27,23 dan kapal Filipina dengan nilai $\mathrm{Ct}$ 34,68. Kenaikan kurva amplifikasi pada analisis real-time PCR menandakan kenaikan konsentrasi DNA, semakin banyak DNA yang terbentuk semakin tinggi pula intensitas fluoresen yang dihasilkan (Bonab et al., 2015). Menurut OIE (2019), nilai Ct < 30 menunjukkan konsentrasi DNA yang tinggi sehingga dinyatakan sebagai sampel positif yang sangat kuat.

Persentase sampel positif 9,09\% (1/11) berasal dari kapal China. Kapal ini memiliki rute perjalanan langsung dari China ke Indonesia. Berdasarkan informasi dari kru kapal stok daging babi dibeli langsung dari China. Laporan dari Zhou et al. (2018) menyebutkan bahwa China merupakan negara pertama terjadinya wabah ASF di Asia sebelum menyebar ke negara Asia lainnya. Wabah ASF di China terjadi pada bulan Agustus 2018 di kota Shenyang, Provinsi Liaoning, dan saat ini dilaporkan sudah menyebar ke 32 provinsi lainnya (FAO, 2021). Saat ini lebih dari 1 juta ekor babi di China dimusnahkan untuk mencegah penyebaran virus ASF (Yun, 2020). China merupakan salah satu produsen dan pemasok daging babi terbesar di dunia dengan populasi babi sekitar 310,41 juta ekor dan produksi daging babi sekitar 55 juta metrik ton setiap tahun (Statista, 2020). Sebagai salah satu negara pemasok daging babi di dunia, China sangat berpotensi dapat menyebarkan virus ASF ke berbagai wilayah dan negara terutama melalui lalu lintas perdagangan. Stok daging babi yang dibawa olah kapal dan dijadikan sebagai menu katering sangat memungkinkan dapat menularkan virus ASF melalui sampah makanan yang diturunkan di pelabuhan.

Persentase sampel positif 33,33\% (1/3) berasal dari kapal Filipina. Kapal ini memiliki rute perjalanan dari Filipina ke Indonesia dengan sebelumnya melakukan transit di China. Berdasarkan informasi dari kru kapal stok daging babi tidak dibeli di Filipina tetapi dibeli pada saat kapal transit di China. Laporan wabah ASF di Filipina dilaporkan pertama kali pada bulan Juli 2019 di Luzon, Mindanao dan Leyte Islands (OIE, 2020). Data OIE (2021) menyebutkan 30\% populasi babi di Filipina menurun dari total populasi babi yang terdapat di 37 Provinsi di Filipina akibat adanya wabah ASF. Populasi babi di Filipina sekitar 9,72 juta ekor dengan produksi daging babi sekitar 515,05 ribu metrik ton setiap tahun (PSA, 2021). Adanya lalu lintas perdagangan melalui kapal laut dari Filipina ke Indonesia berpotensi dalam penyebaran ASF melalui sampah makanan yang diturunkan di pelabuhan. 
Persentase total sampel positif dari sampel sampah makanan kapal laut internasional yang diambil adalah $8,69 \%$ (2/23). Hasil ini tidak jauh berbeda dengan studi Songkasupa et al. (2020) pada tahun 2018-2019 di Thailand, namun menggunakan jenis sampel yang berbeda. Sampel yang diuji adalah produk daging yang berasal dari wisatawan negara tertular ASF yang merupakan hasil sitaan karantina di perbatasan dan pelabuhan internasional Thailand, hasilnya $8,5 \%$ (343/4010) sampel positif mengandung virus ASF. Studi sebelumnya juga dilakukan Wang et al. (2019) terhadap produk babi hasil sitaan karantina yang berasal dari wisatawan negara tertular ASF di bandara dan pelabuhan internasional Taiwan, hasilnya 3,7\% (62/1667) sampel positif mengandung virus ASF.

Hasil pengujian ini sesuai dengan laporan di beberapa negara terkait kemungkinan masuknya ASF melalui pemberian sisa-sisa makanan terkontaminasi pada babi yang berasal dari pelabuhan atau bandar udara yaitu (1) studi Wilkinson (1989) menyebutkan penyebaran ASF pada tahun 1957 dari Angola ke Portugal dan wabah ASF tahun 1970-an di Kuba, Malta, Italia, Brazil dan Republik Dominika dikaitkan dengan pemberian sisa-sisa makanan ke babi dari pelabuhan atau bandar udara, (2) studi Rowlands et al. (2008) menyebutkan bahwa wabah di Georgia pada 2007 terjadi ketika ASF masuk dari Pelabuhan Poti melalui sisa-sisa katering yang terkontaminasi dari suatu kapal kargo internasional yang berasal dari Afrika Tenggara, introduksi ASF ke Georgia ini yang kemudian menyebar ke seluruh Eropa Timur dan Tengah, (3) kejadian ASF pada tahun 2007 di Mauritius, kemungkinan besar masuk melalui pelabuhan dari daging sisa makanan yang terinfeksi yang diberikan ke babi secara ilegal di satu atau lebih bagian pulau tersebut (Lubisi et al., 2009), (4) studi Mur et al. (2012) melaporkan jalur masuknya ASF di Uni Eropa, terutama melalui truk pengangkut babi dan swill feeding dari pesawat dan kapal laut, (5) wabah ASF pada 1968 di Pulau Sardinia, Italia kemungkinan disebabkan oleh introduksi sisa-sisa makanan yang terkontaminasi dari Pelabuhan Cagliari atau bandar udara militer yang digunakan untuk memberi makan babi (Mur et al., 2016), (6) laporan dari FAO (2018) menyebutkan pemasukan ASF ke China terjadi akibat dari lalulintas ternak babi dan barang bawaan, selain itu juga dari rute transportasi seperti truk, pesawat dan kapal laut pengangkut makanan yang terkontaminasi virus ASF, (7) laporan Kolbasov et al. (2018) menyebutkan bahwa produk babi yang terkontaminasi ASF menjadi sumber infeksi paling umum di peternakan skala rumah tangga di Rusia, produk babi yang digunakan untuk pakan babi mempunyai risiko yang besar untuk penyebaran ASF lintas negara maupun lintas benua, dan (8) laporan Zhao et al. (2019) menyebutkan jalur masuknya ASF di beberapa negara di Eropa dan Asia terjadi terutama melalui pemasukan daging babi mentah dan produk olahan baik secara legal maupun ilegal, selain itu juga melalui swill feeding yang berasal dari pesawat atau kapal laut.

Kesimpulan dari penelitian ini adalah 8,69\% (2/23) sampel sampah makanan yang diambil dari kapal laut internasional yang berasal atau transit dari negara tertular ASF yang diturunkan di Pelabuhan Tanjung Priok positif mengandung virus ASF. Sampel positif tersebut berasal dari kapal China dan Filipina. Keberadaan virus ASF pada sampah makanan tersebut menunjukkan indikasi bahwa sampah makanan dari kapal laut internasional dapat menjadi jalur masuknya ASF ke Indonesia.

\section{UCAPAN TERIMA KASIH}

Ucapan terima kasih disampaikan kepada Badan Penyuluhan dan Pengembangan Sumber Daya Manusia Pertanian yang telah memberi dana bantuan penelitian, serta Badan Karantina Pertanian, Balai Besar Karantina Pertanian Tanjung Priok dan Balai Besar Uji Standar Karantina Pertanian yang telah membantu dalam pelaksanaan penelitian.

"Penulis menyatakan tidak ada konflik kepentingan dengan pihak-pihak yang terkait dalam penelitian ini".

\section{DAFTAR PUSTAKA}

Adkin A, England T, Hall S, Coburn H, Marooney $\mathrm{CJ}$, Seaman M, Cooper J, Hartnett E. 2008. Estimating the risk of exposure of British livestock to foot-and-mouth disease associated with the importation of ship and aircraft waste. Veterinary Record. 163(8): 235-240.

Beltran-Alcrudo D, Arias M, Gallardo C, Kramer S, Penrith ML. 2017. African Swine Fever: Detection and Diagnosis - A Manual for Veterinarians. FAO 
Animal Production and Health Manual No. 19. Rome (ITA): Food and Agriculture Organization of the United Nations (FAO).

Beltran-Alcrudo D, Falco JR, Raizman E, Dietze K. 2019. Transboundary spread of pig diseases: The role of international trade and travel. BMC Veterinary Research. 15(1): 1-14.

Bonab MM, Alimoghaddam K, Talebian F, Ghaffari SH, Ghavamzadeh A, Nikbin B, Discher DE, Janmey Pa, WangY-L, Wagner W, Horn P, Castoldi M, Diehlmann A, Bork S, Saffrich R, Benes V, Blake J, Pfister S, Eckstein V, O'Shea KS. 2015. Real-time PCR handbook. Lab Chip. 4(2): 189200.

[CFSPH] Center For Food Security \& Public Health. 2019. Classical swine fever. http://www.cfsph. iastate.edu/Factsheets/pdfs/african_swine_fever. pdf. Unduh 24 Januari 2020.

[EFSA] European Food Safety Authority. 2014. Scientific Opinion on African swine fever EFSA Panel on Animal Health and Welfare (AHAW) 2, 3. https://efsa.onlinelibrary.wiley.com/doi/epdf/10.2 903/j.efsa.2014.3628. Unduh 27 September 2019.

[EFSA] European Food Safety Authority. 2018. Epidemiological analyses of African swine fever in the European Union (November 2017 until November 2018). EFSA Journal. 16(11).

[EMSA] European Maritime Safety Agency. 2017. The management of ship-generated waste onboard ships. http://www.emsa.europa.eu/news-apress-centre/external-news/item/2925-

themanagement-of-ship-generated-waste-onboard-ships.html. Unduh 24 Januari 2020.

[FAO] Food and Agriculture Organization. 2018. ASF China situation update. http://www.fao.org/ag/againfo/programmes/en/e mpres/ASF/2018/Situation_update_2018_12_14.ht ml. Unduh 7 Juni 2020.

[FAO] Food and Agriculture Organization. 2021. ASF situation in Asia \& Pacific update. http://www.fao.org/ag/againfo/programmes/en/e mpres/ASF/situation_update.html. Unduh 13 Februari 2021.

Guinat C, Gogin A, Blome S, Keil G, Pollin R, Pfeiffer DU, Dixon L. 2016. Transmission routes of African swine fever virus to domestic pigs: Current knowledge and future research directions. Veterinary Record. 178(11): 262-267.

[IMO] International Maritime Organization. 2005. Designation of the Baltic Sea Area as a
Particularly Sensitive Sea Area. Resolution MEPC.136(53). Annex 24: 136.

[IMO] International Maritime Organization. 2006. Marpol Consolidation 2006: Annex V-Regulations for the Prevention of Pollution by Garbage from Ships. http://www.marpoltraining.com/MMSKO REAN/MARPOL/Annex_V/index.htm. Unduh 24 Januari 2020.

King DP, Reid SM, Hutchings GH, Grierson SS, Wilkinson PJ, Dixon LK, Bastos ADS, Drew TW. 2003. Development of a TaqMan ${ }^{\circledR}$ PCR assay with internal amplification control for the detection of African swine fever virus. Journal Virology Methods. 107(1): 53-61.

Kolbasov D, Titov I, Tsybanov S, Gogin A, Malogolovkin A. 2018. African swine fever virus, Siberia, Russia, 2017. Emerging Infections Disease. 24(4).

Lubisi BA, Dwarka RM, Meenowa D, Jaumally R. 2009. An investigation into the first outbreak of African swine fever in the Republic of Mauritius. Transboundary Emerging Disease. 56(5): 178-88.

Martin SW, Meek AH, Willeberg P. 1987. Veterinary Epidemiology Principles and Methods. Ames: lowa State University Press. p35-38.

Mazur-Panasiuk N, Zmudzki J, Wozniakowski G. 2019. African swine fever virus - persistence in different environmental conditions and the possibility of its indirect transmission. Journal Veterinary Research. 63: 303-310.

Montgomery RE. 1921. On a form of swine fever occurring in British East Africa (Kenya Colony). Journal of Comparative Pathology. 34: 159-191.

Mur L, Martinez-Lopez B, Sanchez-Vizcaino JM. 2012. Risk of African swine fever introduction into the European Union through transport-associated routes: returning trucks and waste from international ships and planes. BMC Veterinary Research. 8: 1-12.

Mur L, Atzeni M, Martinez-Lopez B, Feliziani F, Rolesu S, Sanchez-Vizcaino JM. 2016. Thirty-fiveyear presence of African swine fever in Sardinia: history, evolution and risk factors for disease maintenance. Transboundary Emerging Disease. 63(2): e165-77.

[OIE] Office International des Epizooties/ World Organization for Animal Health. 2019. Terrestrial Animal Health Code. Infection With African Swine fever Virus. African swine fever-Chapter. https:// www.oie.int/fileadmin/Home/eng/Health_standard s/tahm/3.08.01_ASF. pdf. Unduh 22 Januari 2020. 
[OIE] Office International des Epizooties. 2020. Report 48 current situation of ASF. https://www.oie.int/fileadmin/Home/eng/Animal Health_in_the_World/docs/pdf/Disease_cards/AS F/Report_48_Current_situation_of_ASF.pdf. Unduh 12 Juli 2020.

Oreopoulou V, Tzia C. 2007. Utilization of plant byproducts for the recovery of proteins, dietary fibers, antioxidants, and colorants. Utilization of By-Products and Treatment of Waste in the Food Industry. 209-232.

[Pelindo] PT. Pelabuhan Indonesia II (Persero) Cabang Tanjung Priok. 2020. Jumlah frekuensi kedatangan kapal laut internasional di Pelabuhan Tanjung Priok periode bulan Januari-Mei 2020. Laporan. Dalam: Jumlah frekuensi kedatangan kapal laut internasional di Pelabuhan Tanjung Priok periode bulan Januari-Mei 2020.

Penrith ML, Vosloo W, Jori F, Bastos ADS. 2013. African swine fever virus eradication in Africa. Virus Research. 173(1): 228-246.

[PSA] Philipphine Statistics Authority. 2021. Swine Situation Report, October-December 2020. https://psa.gov.ph/content/swine-

situationreport-october-december-2020. Unduh 13 Februari 2021.

Rowlands RJ, Michaud V, Heath L, Hutchings G, Oura C, Vosloo W, Dwarka R, Onashvili T, Albina E, Dixon LK. 2008. African swine fever virus isolate, Georgia, 2007. Emerging Infectious Disease. 14(12): 1870-1874.

Sendow I, Ratnawati A, Dharmayanti NI, Saepulloh M. 2020. African Swine Fever: Penyakit Emerging yang Mengancam Peternakan Babi di Dunia. WARTAZOA. 30(1): 15.
Songkasupa T, Dokphut A, Boonpornprasert P. 2020. Detection of African swine fever virus in confiscated pork products brought into Thailand during 2018 -2019. Thai Journal of Veterinary Medicine. 257-259.

Statista. 2020. Number of pigs worldwide in 2020, by leading country (in million head). https://www.statista.com/statistics/263964/num ber-of-pigs-in-selected-countries/. Unduh 13 Februari 2021.

Universal Cargo. 2018. How much cargo can the largest shipping container ship really hold?. https://www.universalcargo.com/how-much cargo-can-the-largest-shipping-container-ship-reallyhold/. Unduh 13 Februari 2021.

Wang WH, Lin CY, Chang Ishcol MR, Urbina AN, Assavalapsakul $W$, Thitithanyanont $A$, Lu $P L$, Chen YH, Wang SF. 2019. Detection of African swine fever virus in pork products brought to Taiwan by travellers. Emerging Microbes Infections. 8(1): 1000-1002.

Wilkinson PJ. 1989. African Swine Fever Virus: Virus Infections of Porcines, Vol. II. Pensaert MB, editor. Amsterdam: Elsevier Science Publishers. p17-37.

Yun CH. 2020. Editorial - Unforeseen enemy: African swine fever. Asian-Australas. Journal Animal Science. 33: 1-3.

Zhao D, Liu R, Zhang X, Li F, Wang J, Zhang J, Liu X, Wang L, Zhang J, Wu X, Guan Y, Chen W, Wang X, He X, Bu Z. 2019. Replication and virulence in pigs of the first African swine fever virus isolated in China. Emerging Microbes Infections. 8: 438-447.

Zhou X, Li N, Luo Y, Liu Y, Miao F, Chen T, Zhang S, Cao P, Li X, Tian K et.al. 2018. Emergence of African swine fever in China, 2018. Transboundary Emerging Disease. 65(6): 1482-1484. 